\title{
Paramagnetic properties of Cuban red mud at low temperatures
}

\author{
Valentyna Shvets \\ Institute of Vocational Education; Chapaivske Shose 98, 03-045 Kyiv, Ukraine; e-mail: valentinashvets58@gmail.com \\ (C) 2018 Author. This is an open access publication, which can be used, distributed and reproduced in any medium according \\ to the Creative Commons CC-BY 4.0 License requiring that the original work has been properly cited
}

Received: 27 May 2018; accepted: 13 October 2018; first published online: 31 October 2018

\begin{abstract}
The electron spin resonance (ESR) spectra of Cuban red mud have been measured at three different temperatures: $295 \mathrm{~K}, 150 \mathrm{~K}$ and $77 \mathrm{~K}$. The broad absorption line with resonance fields $\sim(1.7-1.8) \mathrm{kOe}$ was observed at all temperatures with values of $\bar{g}$-factor from 3.602 to 4.020 . The temperature decrease resulted in an absorption line appearance with resonance fields of $3.252 \mathrm{kOe}(\bar{g}=2.067)$ at $150 \mathrm{~K}$ and $3.339 \mathrm{kOe}(\bar{g}=2.086)$ at $77 \mathrm{~K}$. The ESR-signal amplitude with resonance fields $\sim(1.7-1.8) \mathrm{kOe}$ decreases and the ESR-signal amplitude in the field $\sim 3.3 \mathrm{kOe}$ increases with reduction in temperature.
\end{abstract}

Keywords: iron ores, metals oxides, ESR, low temperatures

\section{INTRODUCTION}

Red mud is a secondary product of aluminum extraction in the processing of bauxites using the Bayer method. This product presents a serious problem for recycling, since red muds are polluted with alkalis and heavy metals and pose a danger to the environment. Existing methods of red mud recycling (Linnikov et al. 1999, Tolstokulakova et al. 2009, Pervushin \& Pervushina 2011) are based on chemical and thermal processing. Due to the use of sulfuric acid (Linnikov et al. 1999) and silicon tetrachloride (Tolstokulakova et al. 2009), these methods are both unsafe and costly, while smelting with a reducing agent (Pervushin \& Pervushina 2011) is energetically ineffective. In view of these problems, the study of red mud properties is an urgent task.

Red mud contains oxides and silicates of iron, cobalt, manganese, nickel. Therefore, the solution of the problem of utilization can be approached from the perspective of the investigation of the magnetic properties of these chemical compounds in red mud. Investigations of the magnetic properties of separate components of red mud were carried out: for magnetite $\left(\mathrm{Fe}_{3} \mathrm{O}_{4}\right)$, maghemite $\left(\gamma-\mathrm{Fe}_{2} \mathrm{O}_{3}\right)$, hematite $\left(\alpha-\mathrm{Fe}_{2} \mathrm{O}_{3}\right)$ using ferromagnetic resonance (Can et al. 2012), oxyhydroxide nanoparticles using EPR and SQUID (Carbone at al. 2005), synthetic hematite using ESR (Carbone et al. 2008) and nanomagnetite using ESR (Dobosz et al. 2016). However, the practical interest of the study lies in the behavior of monomineral fractions in the red mud. This article presents the results of studies of the properties of Cuban red mud by means of ESR at the following temperatures: $295 \mathrm{~K}, 150 \mathrm{~K}$ and $77 \mathrm{~K}$, which have been previously partially discussed (Shvets et al. 2012).

\section{THE SAMPLE DATA}

A sample consisting of the concentrated product obtained from Cuban red mud was chosen for investigation. The sample was prepared by 
PJSC SRDI "Mekhanobrchormet" (Kryvyi Rih, Ukraine). The phase composition analysis of the sample was performed on the basis of the difference in magnetic properties of the monomineral fractions using the SALA WGMS 15-20 analyzer. The most significant components of the samples are hematite, iron(III) oxyhydroxides, asbolan (consists of $\mathrm{CoO}, \mathrm{NiO}$ and manganese dioxide), iron silicate, magnetite and chromite. The distinctive feature of the sample is the small percentage of quartz (Tab. 1).

Table 1

The mineralogical structure of the sample [\%]

\begin{tabular}{|c|c|c|c|c|c|c|c|}
\hline 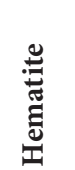 & 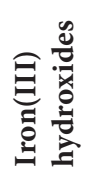 & 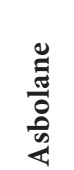 & 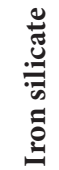 & 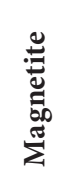 & 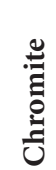 & 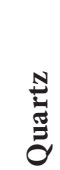 & 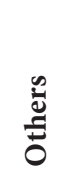 \\
\hline 41.4 & 25.0 & 10.0 & 8.9 & 5.4 & 5.0 & 2.8 & 1.5 \\
\hline
\end{tabular}

Particle size analysis was performed by means of sedimentation. $79.8 \%$ of particles have a size of less than $45 \mu \mathrm{m}, 19.0 \%$ of particles are between $45 \mu \mathrm{m}$ and $74 \mu \mathrm{m}$, while $1.2 \%$ of the particles are larger than $74 \mu \mathrm{m}$.

The test sample originates geologically from the Cretaceous Tholeiitic Arc, which is located in the north-eastern part of Cuba. Ore extraction occurs in three geographical centers located on the Cretaceous Tholeitic Arc: Moa Baracoa (north-eastern part of the Arc), Sagua-de-Tánamo (the central part of the Arc), and Mayari (north-west part of the Arc) (Nelson et al. 2011). These deposits contain chromite melts enriched by $\mathrm{Al}$ in various proportions: from Al-rich $(\mathrm{Cr} \sim 0.45)$ to $\mathrm{Cr}$-rich (Cr 0.78) (Proenza et al. 1999).

\section{MAGNETIC RESONANCE MEASUREMENTS}

The investigations for the sample were carried out with the use of the BRUKER ELEXSYS E580 spectrometer in the X-band. The spectra setup parameters were as follows: the microwave frequency equal to $9.652 \mathrm{GHz}$, the microwave power equal to $0.02 \mathrm{~mW}$, the modulation intensity - $1 \mathrm{G}$, the modulation frequency $-100 \mathrm{kHz}$, the time constant $0.16 \mathrm{~s}$, the sweep time - $300 \mathrm{~s}$, the samples weight was $(16 \pm 1) \mathrm{mg}$, the temperature was $295 \mathrm{~K}, 150 \mathrm{~K}$ and $77 \mathrm{~K}$. The Dewar container, made from foam plastic and filled with liquid nitrogen, was used to obtain the spectrum at $77 \mathrm{~K}$. The ESR absorption curves with the forward and reverse directions of the magnetic field are presented in Figure 1, as a derivative of absorption function.

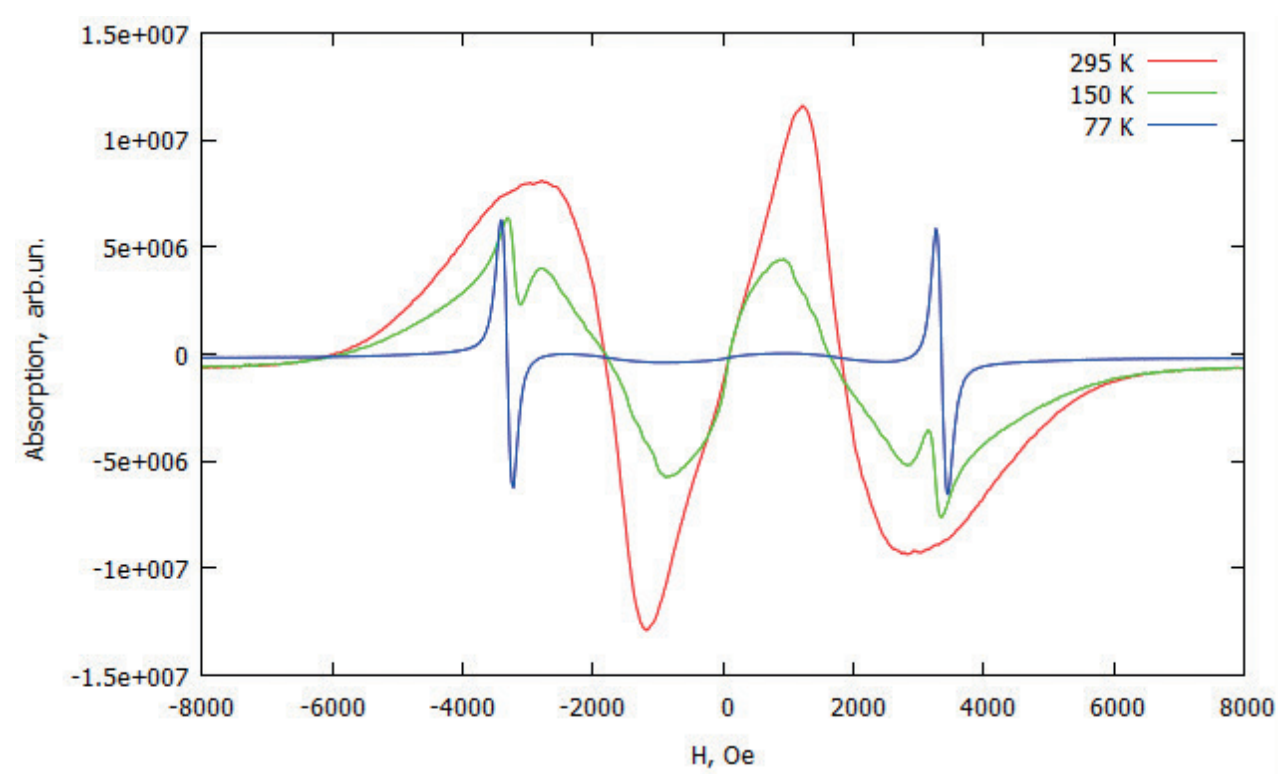

Fig. 1. ESR absorption by the Cuban red mud at $295 \mathrm{~K}, 150 \mathrm{~K}$ and $77 \mathrm{~K}$ 
We can see from Figure 1 that the absorption line at $295 \mathrm{~K}$ is observed with resonance field $1.821 \mathrm{kOe}$. This line is broad, as it has been shown previously for $295 \mathrm{~K}$ only (Shvets et al. 2010).

With the temperature decreasing to $150 \mathrm{~K}$, a new absorption line with a resonance field of $3.252 \mathrm{kOe}$ was observed. At the same time, the reduction of the ESR-signal amplitude with resonance field $1.821 \mathrm{kOe}$ and the shift of this line to the field $1.761 \mathrm{kOe}$ were also observed.

With a further temperature decrease to $77 \mathrm{~K}$, a clearly visible line with a resonance field $3.339 \mathrm{kOe}$ was discerned, together with a line of small intensity with a resonance field $1.672 \mathrm{kOe}$. It should be noted that the line shape of $\sim 3.3 \mathrm{kOe}$ ( $3.252 \mathrm{kOe}$ at $150 \mathrm{~K}$ and $3.339 \mathrm{kOe}$ at $77 \mathrm{~K}$ ) is similar to the ESR line shape for paramagnetic centers with one unpaired electron, where the transition occurs between states with energy values $(-1 / 2 g \beta H)$ and $1 / 2 g \beta H$ (Drago 1977).

The appearance of the new absorption line with a resonance field $\sim 3.3 \mathrm{kOe}$ was accompanied by a change in $\bar{g}$-factor (Tab. 2 ).

Table 2

The values of $H_{r e s}$ and $\bar{g}$-factor measured at different temperatures

\begin{tabular}{|c|c|c|}
\hline $\boldsymbol{T}[\mathrm{K}]$ & $\boldsymbol{H}_{\text {res }}[\mathrm{kOe}]$ & $\overline{\boldsymbol{g}}$-factor \\
\hline 295 & 1.821 & 3.602 \\
\hline \multirow{2}{*}{150} & 1.761 & 4.016 \\
& 3.252 & 2.067 \\
\hline \multirow{2}{*}{77} & 1.672 & 4.020 \\
& 3.339 & 2.086 \\
\hline
\end{tabular}

We see that values of $\bar{g}$-factor for the lines with resonance fields $\sim(1.7-1.8) \mathrm{kOe}$ and the line with resonance field $\sim 3.3 \mathrm{kOe}$ differ significantly: the average value of the effective $\bar{g}$-factor at $295 \mathrm{~K}$ for the line $1.821 \mathrm{kOe}$ is equal to $3.602, \bar{g}$-factor for the line $\sim 3.3 \mathrm{kOe}$ at $150 \mathrm{~K}$ and at $77 \mathrm{~K}$ is equal to 2.067 and 2.086 respectively; $\bar{g}$-factor for the line in the field $1.7 \mathrm{kOe}$ is equal to 4.016 at $150 \mathrm{~K}$ and 4.020 at $77 \mathrm{~K}$.

The temperature decrease leads to a reduction in the ESR-signal amplitude for absorption lines with resonance fields $\sim(1.7-1.8) \mathrm{kOe}$. At the same time, the temperature decrease leads to an increase of the ESR-signal amplitude for absorption lines with resonance fields $\sim 3.3 \mathrm{kOe}$ (Tab. 3 ).
Table 3

The amplitude of the ESR-signal at different temperatures

\begin{tabular}{|c|c|c|}
\hline \multirow{2}{*}{$T[\mathrm{~K}]$} & \multicolumn{2}{|c|}{ The amplitude $\left[\mathbf{1 0}^{\mathbf{6}}\right.$ arb. un. $]$} \\
\cline { 2 - 3 } & $\begin{array}{c}\text { in the field } \\
\sim(\mathbf{1 . 7}-\mathbf{1 . 8}) \mathbf{~ k O e}\end{array}$ & $\begin{array}{c}\text { in the field } \\
\sim 3.3\end{array}$ \\
\hline 295 & 10.5 & - \\
\hline 150 & 4.8 & 2.1 \\
\hline 77 & 0.2 & 6.2 \\
\hline
\end{tabular}

\section{DISCUSSION}

We can see from Table 1 that the studied sample contains a number of ions of the transition metal atoms that are part of separate monomineral fractions. The sample mainly consists of hematite and iron(III) oxyhydroxides, which contains of ions $\mathrm{Fe}^{3+}$. Asbolane, expressed with the chemical formula $(\mathrm{Co}, \mathrm{Ni}) \mathrm{O} \cdot \mathrm{MnO}_{2} \cdot n \mathrm{H}_{2} \mathrm{O}$, contains the ions $\mathrm{Ni}^{2+}, \mathrm{Co}^{2+}, \mathrm{Mn}^{4+}$. Asbolane is mixed-layer mineral with layers of $\mathrm{Mn}-\mathrm{O}$ octahedra and other metals mostly in separate layers (Palache et al. 1944). Iron silicate, $\mathrm{Fe}_{2} \mathrm{SiO}_{4}$, contains the ions $\mathrm{Fe}^{2+}$. Magnetite, $\mathrm{FeO} \cdot \mathrm{Fe}_{2} \mathrm{O}_{3}$, contains the ions $\mathrm{Fe}^{2+}$ and $\mathrm{Fe}^{3+}$. Chromite, $\mathrm{FeO} \cdot \mathrm{Cr}_{2} \mathrm{O}_{3}$, contains the ions $\mathrm{Fe}^{2+}$ and $\mathrm{Cr}^{3+}$. The majorities of these ions have an uncompensated spin magnetic moment and may potentially be the source of the ESR signal (Tab. 4).

Table 4

Electronic configurations of ions in Cuban red mud

\begin{tabular}{|l|c|c|c|c|c|c|}
\hline Ion & $\mathrm{Cr}^{3+}$ & $\mathrm{Mn}^{4+}$ & $\mathrm{Fe}^{2+}$ & $\mathrm{Fe}^{3+}$ & $\mathrm{Co}^{2+}$ & $\mathrm{Ni}^{2+}$ \\
\hline $\begin{array}{l}\text { Electronic } \\
\text { configuration }\end{array}$ & $3 d^{3}$ & $3 d^{3}$ & $3 d^{6}$ & $3 d^{5}$ & $3 d^{7}$ & $3 d^{8}$ \\
\hline
\end{tabular}

We can see from Table 4 that ions with an odd number of $3 d$-electrons, namely: $\mathrm{Fe}^{3+}, \mathrm{Mn}^{4+}, \mathrm{Cr}^{3+}$ and $\mathrm{Co}^{2+}$, can contribute to the wide absorption line in the region of $1.8 \mathrm{kOe}$ at room temperature. This is confirmed not only by the wide absorption line in this region, but also by the value of the $\bar{g}$-factor. The absorption line of pure hematite was observed in this region (Carbone et al. 2008), however, the $\bar{g}$-factor for this transition was equal to 2.1. In this article the $\bar{g}$-factor is 3.6.

As the temperature decreases, a number of magnetic transitions occur in the monomineral fractions contained in the sample. 


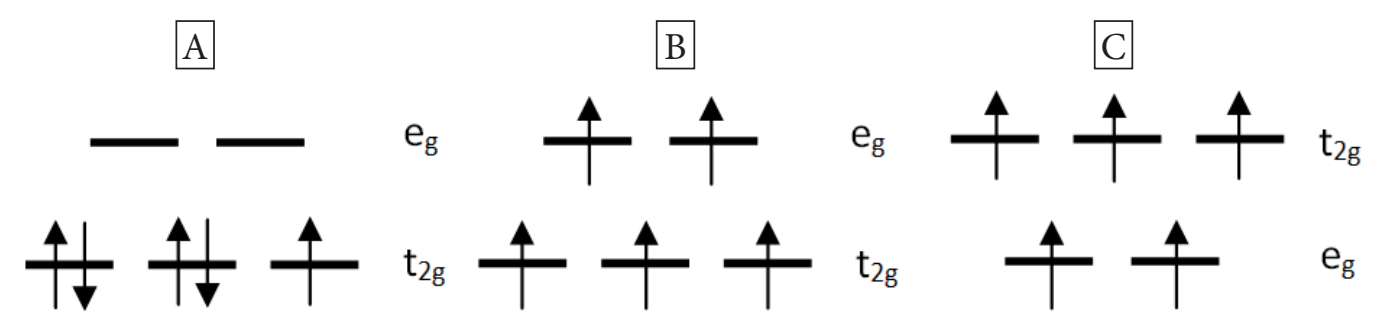

Fig. 2. The distribution of electrons along the orbitals for the $\mathrm{Fe}^{3+}$ ion: A) in the octahedral field of ligands in the case of a strong bond (term $\left.{ }^{2} T_{2 \mathrm{~g}}\right) ; B$ ) in the octahedral field of ligands in the case of weak coupling (term ${ }^{6} A_{1 \mathrm{~g}}$ ); in the tetrahedral field of ligands in the case of weak coupling $\left({ }^{6} A_{1 \mathrm{~g}}\right)$

In hematite, transitions associated with a change in the angle of inclination of antiferromagnetic sublattices are observed. In the crystal $\alpha-\mathrm{Fe}_{2} \mathrm{O}_{3}$ in the temperature range from $250 \mathrm{~K}$ to $261 \mathrm{~K}$, the Morin transition occurs (Özdemir et al. 2008). The magnetic transition, similar to the Morin transition, is observed in the temperature range from $130 \mathrm{~K}$ to $80 \mathrm{~K}$ in $\varepsilon-\mathrm{Fe}_{2} \mathrm{O}_{3}$ and is associated with a decrease in the skew of the antiferromagnetic sublattices (Gich et al. 2006a, 2006b). The decrease in the amplitude of the ESR-signal with a resonance field $\sim(1.7-1.8) \mathrm{kOe}$ at low temperatures can be due to structural changes occurring with iron oxides: paramagnetic hematite becomes antiferromagnetic goethite at $150 \mathrm{~K}$ according to calculations by DFT (Yu et al. 2016). The change in the structural characteristics of the sample at low temperatures might explain the small shift of the absorption region.

In magnetite at temperatures below $T_{V}=120 \mathrm{~K}$, the Verwey transition is observed (Verwey 1939). It has been shown (Senn 2012) that magnetite generates large-radius polarons (trimerons) at $77 \mathrm{~K}$ with the participation of $\beta t_{2 g}$ electrons, the donors of which are $\mathrm{Fe}^{2+}$ ions in the octahedral positions of magnetite. As a result of this charge ordering, the ion $\mathrm{Fe}^{2+}$ is converted to the ion $\mathrm{Fe}^{3+}$, whose state is described by the ${ }^{2} T_{2 g}$ state (it derives from the crystal field theory, Fig. 2A), in a contrast to $\mathrm{Fe}^{3+}$ ions in octahedral and tetrahedral positions already existing in the crystal, described by the ${ }^{6} A_{1 g}$ term (Fig. 2B, 2C).

Consequently, the unpaired $\alpha t_{2 g}$-electron of the ion $\mathrm{Fe}^{3+}$ formed from the ion $\mathrm{Fe}^{2+}$ (Fig. 2A) during the formation of the polaron might be responsible of the line in the region of $3.3 \mathrm{kOe}$, causing paramagnetic properties of the sample at $77 \mathrm{~K}$.
It was revealed that $\mathrm{MnO}_{2}$, which contains the paramagnetic ion $\mathrm{Mn}^{4+}$, becomes antiferromagnetic at $77 \mathrm{~K}$ and does not appear in the ESR spectrum (Kakazey at al. 2001), therefore, it does not support the line in the region of $3.3 \mathrm{kOe}$.

Pure chromite, or chromospinel $\mathrm{FeO} \cdot \mathrm{Cr}_{2} \mathrm{O}_{3}$, exhibits weak magnetic properties at room temperatures. It was observed the ESR absorption for $\mathrm{Cr}^{3+}$ in an octahedral field with $\bar{g}=1.903$, and also for $\mathrm{Fe}^{3+}$ with $\bar{g}=3.861$ at room temperature for samples of Cuban chromite, which, as the test sample, belongs to Cretaceous Tholeiitic Arc (Reddy \& Frost 2005). In our spectra, we observe only a broad band with $\bar{g}=3.602$ at $295 \mathrm{~K}$, the carrier of which is the ion $\mathrm{Fe}^{3+}$, as already mentioned above.

Bulk $\mathrm{CoO}$ is antiferromagnetic with a Néel temperature at $298 \mathrm{~K}$, so it does not appear in the ESR spectrum at $77 \mathrm{~K}$.

Thus, it can be concluded from the analysis that:

- the absorption band in the region of $1.821 \mathrm{kOe}$ can be formed by the ions $\mathrm{Fe}^{3+}$, which are part of hematite, oxyhydroxides, fayalite, chromite, magnetite, as well as by the $\mathrm{Mn}^{4+}$ ions that make up $\mathrm{MnO}_{2}$;

- the carrier of the ESR signal in the region $\sim 3.3 \mathrm{kOe}$ is the $\alpha t_{2 g}$-electron of the ion $\mathrm{Fe}^{3+}$ formed from the ion $\mathrm{Fe}^{2+}$ during the formation of trimeron in magnetite.

\section{CONCLUSIONS}

The investigation of the sample of Cuban red mud using the ESR method revealed the following features of ESR absorption:

1. Broad absorption lines with a resonance field of 1.821 kOe with $\bar{g}=3.602$ were observed in the ESR spectra at $T=295 \mathrm{~K}$; temperature 
decreases to $150 \mathrm{~K}$ and $77 \mathrm{~K}$ lead to the shift of the absorption into the fields $1.761 \mathrm{kOe}$ and $1.672 \mathrm{kOe}$ respectively.

2. Absorption lines with resonance fields of 3.252 and $3.339 \mathrm{kOe}$ were observed in the sample at $150 \mathrm{~K}$ and $77 \mathrm{~K}$ respectively.

3. ESR-signal amplitudes with resonance fields of $\sim(1.7-1.8) \mathrm{kOe}$ decrease with the reduction in temperature; the ESR-signal amplitudes with the fields $3.252 \mathrm{kOe}$ and $3.339 \mathrm{kOe}$ increase with the decrease of the temperature.

It should be noted that the similar changes of magnetic properties at low temperatures can appear in other samples containing hematite and magnetite.

From the results of the measurements listed above it follows that observed changes in magnetic properties of Cuban red mud at low temperatures should be considered when developing new technologies for recycling bauxite secondary products.

This work was supported by the research grant "The investigation of weakly magnetic ores by resonance methods", financed by the government of Ukraine.

The author is grateful to Prof. Dr. M. Jałochowski (Head of the Department of the Surface Physics and Nanostructure of the Maria Curie-Skłodowska University in Lublin, Poland) for the useful discussion of this work, A.K. Melnyk (Institute of Sorption and Problems of Endoecology of National Academy of Science of Ukraine) for the ESR-spectra, Dr. V.D. Maly (PJSC SRDI "Mekhanobrchormet”, Ukraine) for the sample preparation.

\section{REFERENCES}

Can M., Coşkun M. \& Firat T., 2012. A comparative study of nanosized iron oxide particles: magnetite $\left(\mathrm{Fe}_{3} \mathrm{O}_{4}\right)$, maghemite $\left(\gamma-\mathrm{Fe}_{2} \mathrm{O}_{3}\right)$ and hematite $\left(\alpha-\mathrm{Fe}_{2} \mathrm{O}_{3}\right)$, using ferromagnetic resonance. Journal of Alloys and Compounds, 542, 241-247, DOI: https://doi.org/10.1016/ j.jallcom.2012.07.091

Carbone C., Di Benedetto F., Sangregorio C., Marescotti P., Pardi L. \& Sorace L., 2008. Multifrequency EMR and Magnetic Characterization of Synthetic Powdered Hematite. Journal of Physical Chemistry C, 112, 27, 9988 9995, DOI: https://doi.org/10.1021/jp712045s.

Carbone C., Di Benedetto F., Marescotti P., Sangregorio C., Sorace L., Lima N., Romanelli M., Lucchetti G. \& Cipriani C., 2005. Natural Fe-oxide and oxyhydroxide nanoparticles: an EPR and SQUID investigation. Mineralogy and Petrology, 85, 1-2, 19-32.

Dobosz B., Krzyminiewski R., Koralewski M. \& Hałupka-Bryl M., 2016. Computer enhancement of ESR spectra of magnetite nanoparticles. Journal of Magnetism and Magnetic Materials, 407, 114-121, DOI: https://doi. org/10.1016/j.jmmm.2016.01.058.

Drago R., 1977. Physical Methods in Chemistry. Saunders College Company, Philadelphia - London - Toronto.

Gich M., Frontera C., Roig A., Fontcuberta J., Molins E., Bellido N., Simon Ch. \& Fleta C., 2006a. Magnetoelectric coupling in $\varepsilon-\mathrm{Fe}_{2} \mathrm{O}_{3}$ nanoparticles. Nanotechnology, 17, 3 , 687-691.

Gich M., Frontera C., Roig A., Taboada E., Mollins E., Rechenberg H., Ardison J., Macedo W., Ritter C., Hardly V., Sort J., Skumryev V. \& Nogués J., 2006b. Highand Low-Temperature Crystal and Magnetic Structures of $\varepsilon-\mathrm{Fe}_{2} \mathrm{O}_{3}$ and Their Correlation to Its Magnetic Properties. Chemistry of Materials, 18, 16, 3889-3897, DOI: https://doi.org/10.1021/cm0609931.

Kakazey M., Ivanova N., Sokolsky G. \& Gonzales-Rodrigues J., 2001. Electron Paramagnetic Resonance of $\mathrm{MnO}_{2}$ powders. Electrochemical and Solid-state Letters, 4, 5, 1-4.

Linnikov O.D., Yatsenko S.P. \& Sabirzyanov N.A, 1999. Sposob pererabotki krasnogo shlama. Patent RU 2140998 [Линников О.Д., Яценко С.П. \& Сабирзянов Н.А., 1999. Способ переработки красного шлама. Патент России 2140998], [on-line:] http://www.findpatent.ru/ patent/214/2140998.html [access: 30.04.2018].

Nelson C.E., Proenza J.A., Lewis J.F. \& López-Kramer J., 2011. The metallogenic evolution of the Greater Antilles. Geologica Acta, 9, 3-4, 229-264, DOI: https://doi. org/10.1344/105.000001741.

Özdemir Ö., Dunlop D. \& Berquó T., 2008. Morin transition in hematite: Size dependence and thermal hysteresis. Geochemistry, Geophysics, Geosystem, 9, 10, 1-12, DOI: https://doi.org/10.1029/2008GC002110.

Palache C., Berman H. \& Frondel C., 1944. The System of Mineralogy of James Dwight Dana and Edward Salisbury Dana: Yale University, 1837-1892. Volume 1: Elements, Sulfides, Sulfosalts, Oxides. John Wiley and Sons, Lincoln (UK).

Pervushin N.G. \& Pervushina V.P, 2011. Sposob pererabotki krasnykh shlamov. Patent RU 2428490 [Первушин Н.Г. \& Первушина В.П., 2011. Способ переработки красных шламов. Патент России 2428490], [on-line:] http://www.findpatent.ru/patent/242/2428490.html [access: 30.04 .2018 ].

Proenza J., Gervilla F., Melgarejo J.C. \& Bodinier J.L., 1999. Aland Cr-rich chromitites from the Mayarí-Baracoa Ophiolitic Belt (eastern Cuba): consequence of interaction between volatile-rich melts and peridotites in suprasubduction mantle. Economic Geology, 94, 547-566.

Reddy B. \& Frost R., 2005. Spectroscopic characterization of chromite from the Moa-Baracoa Ophiolitic Massif, Cuba. Spectrochimica Acta, Part A: Molecular and Biomolecular Spectroscopy, 61, 5, 1721-1728, DOI: https:// doi.org/10.1016/j.saa.2004.07.002.

Senn M., Wright J. \& Attfield J., 2012. Charge order and threesite distortions in the Verwey structure of magnetite. $\mathrm{Na}$ ture, 481, 7380, 173-176, DOI: https://doi.org/10.1038/nature10704. 
Shvets V., Melnyk A., Trachevskyj V. \& Gerasimchuk A. 2010. The investigation of the low magnetic iron ores by EPR and their component FeO by DFT. Journal of Molecular Structure THEOCHEM, 954, 1-3, 94-97, DOI: https://doi.org/doi.org/10.1016/j.theochem.2010.01.035.

Shvets V., Trachevskyj V. \& Melnyk A., 2012. The properties of low magnetic iron ores at low temperatures. [in:] Hubicki Z. (red.), Nauka i przemysł: metody spektroskopowe w praktyce, nowe wyzwania i możliwości, Wydawnictwo Uniwersytetu Marii Curie-Skłodowskiej, Lublin, 480-486.

Tolstokulakova A.V., Garmazov Yu.L., Zaydes S.A. \& Turchanoniv V.K., 2009. Sposob pererabotki krasnykh shlamov. Patent RU 2360981 [Толстокулакова А.В., Гарма- зов Ю.Л., Зайдес С.А., Турчанинов В.К., 2009. Способ переработки красньх иламов. Патент России 2360981], [on-line:] http://www.findpatent.ru/patent/ 236/2360981.html [access: 30.04.2018].

Verwey E., 1939. Electronic Conduction of Magnetite $\left(\mathrm{Fe}_{3} \mathrm{O}_{4}\right)$ and Its Transition Point at Low Temperatures. Nature, 144, 327-328,DOI: https://doi.org/10.1038/144327b0.

Yu M., Liu X., Huo C.-F., Guo W., Cao D.-B., Peng Q., Dearden A. K., Gonzo X., Yang Y., Wang J., Jiao H., Li Y.-W. \& Wen X.-D., 2016. When density functional approximation meet iron oxides. Journal of Chemical Theory and Computation, 12, 10, 5132-5144, DOI: https://doi.org/10.1021/acs. jctc.6b00640. 